\title{
Revisiting Remane's concept: evidence for high plankton diversity and a protistan species maximum in the horohalinicum of the Baltic Sea
}

\author{
Irena V. Telesh ${ }^{1, *}$, Hendrik Schubert $^{2}$, Sergei O. Skarlato ${ }^{3}$ \\ ${ }^{1}$ Zoological Institute, Russian Academy of Sciences, Saint Petersburg 199034, Russia \\ ${ }^{2}$ Institute of Biological Sciences, University of Rostock, Rostock 18051, Germany \\ ${ }^{3}$ Institute of Cytology, Russian Academy of Sciences, Saint Petersburg 194064, Russia
}

ABSTRACT: Ecological and evolutionary processes have shaped current biodiversity patterns. For brackish-water ecosystems, Remane's Artenminimum ('species minimum') concept argues that taxonomic diversity in organisms is lowest within the horohalinicum, which occurs at salinity 5 to 8 . This concept developed from macrozoobenthos data; it originated from, and is still applied to, the geologically young Baltic Sea, the world's largest semi-enclosed, brackish water body with a unique permanent salinity gradient. We re-assessed pelagic biodiversity in the Baltic Sea, which had long remained underestimated. We show that phyto- and zooplankton in Baltic waters exhibit unexpectedly high diversity (>4000 taxa), with dominance by protists. Protists in the Baltic Sea follow a binomial distribution mode, while metazooplankton diversity decreases exponentially with higher salinity; however, species richness of both groups peaks in the horohalinicum. Drifting within large water masses, planktonic organisms are affected by only moderate salinity fluctuations (compared to benthic species), and thus prosper in brackish environments. The present study challenges Remane's concept for large water bodies with relatively stable salinity gradients and substantiates a novel ecological perspective of the previously overlooked high protistan diversity in brackish waters. We infer that the pronounced adaptability and advanced osmoregulation strategies of protists are the result of large-scale ecological and evolutionary processes. The novel brackish-water biodiversity pattern underpins the proposed protistan species-maximum concept, which refines Remane's model by discriminating between the effects of the horohalinicum on the biodiversity of small motile versus large sessile organisms.

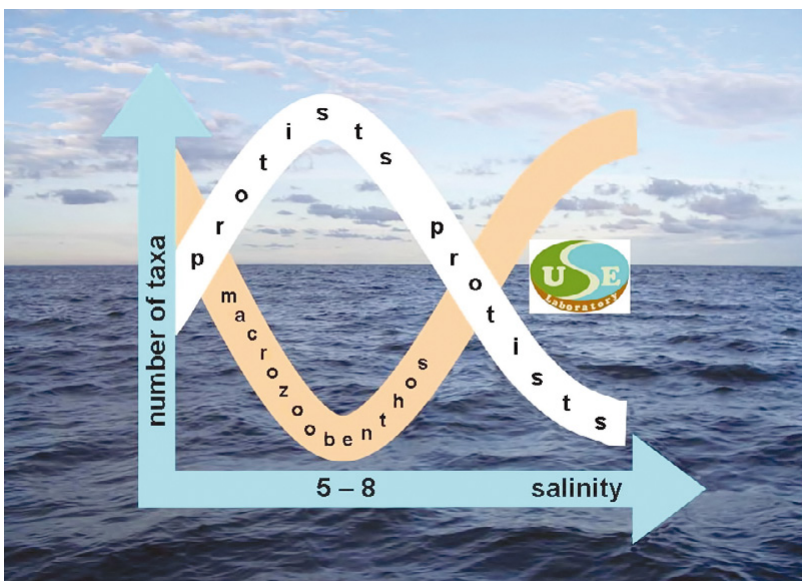

High protistan species diversity in the horohalinicum of the Baltic Sea found by the members of the Ulrich Schiewer Laboratory for Experimental Aquatic Cytoecology (USE Laboratory) challenges Remane's classic Artenminimum model

Image: Irena Telesh

KEY WORDS: Salinity gradient - Horohalinicum • Species diversity . Protists . Phytoplankton. Zooplankton · Brackish waters · Baltic Sea Resale or republication not permitted without
written consent of the publisher

\section{INTRODUCTION}

Spatial heterogeneity in species richness in the natural world may be expressed by only a limited number of broad-scale biodiversity patterns (Gaston 2000). Geomorphological settings and environmental conditions play a primary role in shaping the patterns of natural 
biological diversity, although it remains an open question whether more species are facilitated or excluded from communities by environmental fluctuations (Shurin et al. 2010). Examination of the variability in environmental conditions is key to assessing the present state of ecosystems and forecasting future biodiversity scenarios under human impact and global climate change (de Jonge \& de Jong 2002, Shurin et al. 2010).

In aquatic ecosystems, salinity is the environmental factor of utmost importance. Extreme salinity values and long-term salinity variations define the heterogeneity of habitats and species richness of aquatic communities (de Jonge 1974, Michaelis et al. 1992, Attrill 2002). Until recently, it was accepted that variable environmental conditions in brackish water bodies tend to exclude species (e.g. McLusky \& Elliott 2004) and, thus, estuaries and other 'transitional' marine-freshwater areas host speciespoor communities, demonstrating the Artenminimum ('species minimum') best shown by Remane (1934).

This concept was widely applied to the Baltic Sea (Fig. 1), the largest semi-enclosed, generally tideless, brackish water basin in the world, located between 10 and $30^{\circ} \mathrm{E}$ and between 54 and $66^{\circ} \mathrm{N}$, with a waterresidence time of 25 to $35 \mathrm{yr}$, surface area of about $4.2 \times 10^{5} \mathrm{~km}^{2}$ and volume of about $22 \times 10^{3} \mathrm{~km}^{3}$, representing ca. 0.1 and $0.002 \%$ of the world's ocean area and volume, respectively (Lass \& Matthäus 2008, Ojaveer et al. 2010). The Baltic Sea is a geologically young water body that was formed after the last glaciation,

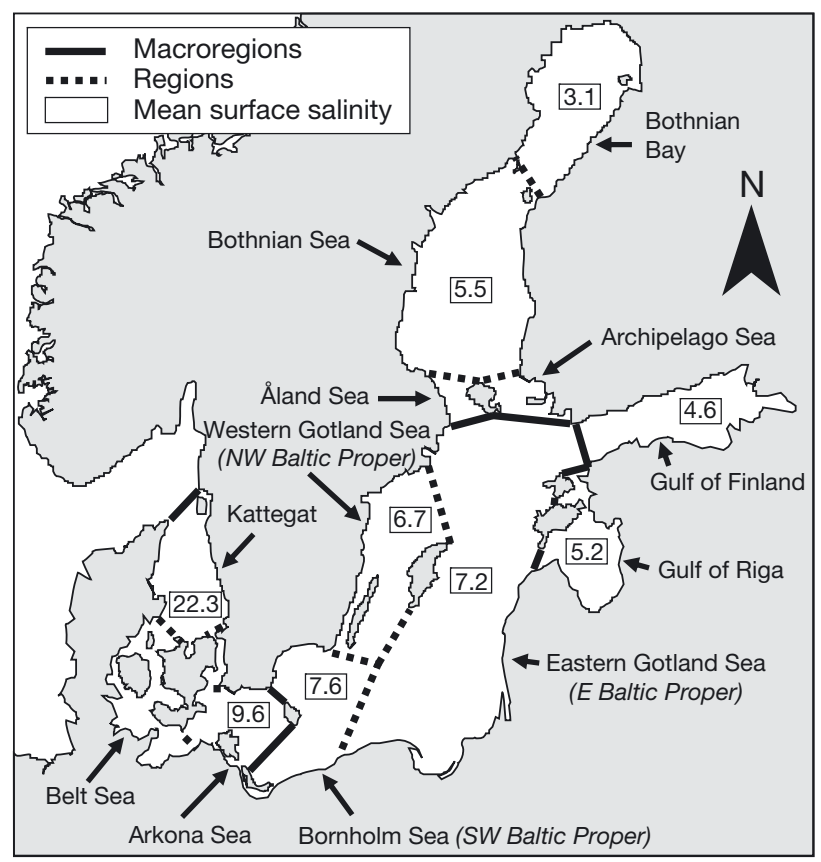

Fig. 1. Scheme of the Baltic Sea indicating the regions and natural macroregions according to Wattenberg (1949), and mean surface-water salinity (calculated from Feistel et al. 2010) has undergone remarkable shifts in basic physicochemical characteristics during a geologically short time period, and has existed within its present borders for no more than 10000 yr (Lass \& Matthäus 2008, Schiewer 2008). Niche occupation is still in progress in the Baltic, well illustrated by the high rate of unintentional biological invasions through different natural and human-mediated pathways from other marine and freshwater basins (Paavola et al. 2005, Schiewer 2008, Telesh et al. 2008b, 2009, Ojaveer et al. 2010).

The Baltic was thought to be a species-poor water body because the average surface-water salinity in the Baltic Sea proper is 5 to $8-$ a critical level at which sharp changes in the ionic composition of seawater diluted with freshwater occur (Khlebovich 1968). Khlebovich (1969) argued that these ionic changes constitute a physico-chemical barrier between marine and freshwater faunas, and Kinne (1971) coined the name 'horohalinicum' (from the Greek 'horos': limit, boundary line) for this specific salinity range. Khlebovich \& Abramova (2000) defined the horohalinicum as a salinity zone that always corresponds to salinity 5 to 8 and divides freshwater and marine faunas and floras, as well as having many other physico-chemical characteristics. It is generally accepted that the horohalinicum in estuaries provides unfavourable osmotic conditions for aquatic organisms, impeding high species diversity and causing the Artenminimum effect, since considerable hypo- and hyperosmotic adjustments are required within this zone (Telesh \& Khlebovich 2010).

However, the horohalinicum concept and its basic tenets were not without debate in the literature. Deaton \& Greenberg (1986) stated that species abundance declined to a minimum between salinity 5 and 8 not only in estuaries, but in all bodies of brackish water. Those authors re-examined the hydrochemical data used by Khlebovich (1968) and found that, in fact, while the ionic composition of diluted seawater changed slightly between salinity 5 and 8 , the changes in ionic ratios below salinity 2 were much larger; thus it was concluded that the proposed physico-chemical barrier did not exist only between salinity 5 and 8 . The latter finding fits well with the idea of plurality of barrier salinity zones and the existence of the specific ' $\delta$-horohalinicum' at salinity 0.5 to 2.0 (Aladin 1988).

Moreover, 2 possible ecological explanations for the occurrence of the Artenminimum-a species-area relationship and the stability-time hypothesis-were found to be inconsistent with the published data on species distributions in brackish waters (Deaton \& Greenberg 1986 and references therein). Deaton \& Greenberg (1986) suggested that low species diversity in brackish water may be explained, in part, by 2 factors: (1) few animals evolve the physiological mechanisms required for life in this variable habitat; and 
(2) brackish water species, which are very eurytopic, have low rates of speciation compared to more stenotopic marine or freshwater species.

The original Artenminimum conceptual assertions were largely based on the Baltic Sea hydrobiological data of Remane (1934) and best illustrated by Remane's curve (see Fig. 2A) - a diagram grounded on field observations on macrozoobenthos (Porifera, Hydrozoa, Scyphozoa, Anthozoa, Nemertini, Polychaeta, Cumacea, Mysidacea, Amphipoda, Decapoda, Lamellibranchia, Ophistobranchia, Echinodermata, Ascidiae and some others) and Ctenophora (Remane 1934, Remane \& Schlieper 1971). The Remane model described the distribution of marine, freshwater and brackish-water benthic invertebrate diversity along a marine-freshwater salinity gradient in the Baltic Sea, with the overall minimum number of species to be found within the horohalinicum. Remane's model was supported by other authors researching bottomdwelling fauna (e.g. Zenkewitch 1959) and by a number of subsequent influential publications (e.g. Wolff 1983). The work of Remane along with publications by Välikangas $(1926,1933)$ and Redeke (1933) contributed significantly to the development of general classifications of waters according to salinity, and several amendments have been made to put the existing concepts into an even broader perspective (Venice System 1959).

Meanwhile, some zoobenthos studies in estuaries demonstrated a marked departure from the Remane model (Boesch et al. 1976, Attrill 2002). Moreover, it was shown that for zooplankton (including ciliates and bacteria), Remane's model is inapplicable, as planktonic organisms often do not show minimum species diversity in the intermediate zone between marine and freshwater (Laprise \& Dodson 1994, Crump et al. 1999, Dolan \& Gallegos 2001, Hewson \& Fuhrman 2004, Telesh 2004). Species diversity in phytoplankton also did not display a minimum within the marine-freshwater salinity gradient of the estuary of the Schelde River (Muylaert et al. 2009), although this important observation may be largely due to the density-driven accumulation of suspended material (organisms included) that contributes to the estuarine turbidity maximum in meso- and macrotidal estuaries. Additionally, different opinions on whether or not genuine brackishwater species exist (e.g. Remane 1958 but Remane 1969, Barnes 1989, Attrill 2002) challenge Remane's curve. Nevertheless, independently of those departures and despite basic differences between the generally tideless Baltic Sea and the majority of tidal estuaries, the Baltic Artenminimum diagram of Remane has become the recognised textbook model for the diversity of all organisms in the salinity gradient, also in tidal estuaries (McLusky \& Elliott 2004).
The Baltic zooplankton in Remane's time was poorly studied, totaling ca. 40 species (Remane 1934, Hernroth \& Ackefors 1979), and this number fitted well to the species-minimum notion developed for macrozoobenthos. Later on, the extensive revised calculations of phyto- and zooplankton biodiversity demonstrated high species richness for planktonic organisms (bacteria were not considered) in the Baltic Sea (Telesh \& Heerkloss 2002, 2004, Hällfors 2004, Sagert et al. 2008, Telesh et al. $2008 a, b, 2009)$. These results suggest that the diversity of small, fast-reproducing planktonic organisms in brackish environments with long water-residence time (which allows enough time for evolutionary processes for microplankters) may be greater than that of benthic macrofauna, thus providing a basis for certain adjustments to Remane's species-minimum concept. Unlike bottomdwelling animals, planktonic organisms drift within large water masses and, thus, experience less stress from moderate salinity fluctuations than sedentary benthic organisms. This assumption is in concordance with the intermediate disturbance hypothesis (Connell 1978) and resource competition theory (e.g. Tilman 1982, Grover 1997, Huisman \& Weissing 1999, 2001); it is also supported by the body-size dependency of the evolutionary rate and the species-area relationships developed for protists (Fenchel \& Finlay 2004).

To validate the hypothesis that small-sized fastevolving protists can fill in the biodiversity gap in brackish waters, we re-examined the overall plankton diversity in the Baltic Sea, with special emphasis on eukaryotic microplankton (protists) and their distribution within the salinity gradient. We infer that pronounced adaptability to salinity fluctuations (Stock et al. 2002), as demonstrated by many cosmopolitan protists (Fenchel \& Finlay 2004), and the advanced osmoregulation strategies of these tiny organisms, are the results of large-scale ecological and evolutionary processes in aquatic ecosystems (Fuhrman 2009) that underpin the striking plankton diversity in the horohalinicum of the Baltic Sea and the novel protistan species-maximum concept. The present study, thus, challenges the Remane Artenminimum model (Remane 1934) and substantiates an important ecological perspective of the previously overlooked protistan diversity in brackish waters.

\section{MATERIALS AND METHODS}

We conducted a meta-analysis of large phytoplankton data sets (Sagert et al. 2008), comprehensive phytoplankton species lists (Hällfors 2004), long-term studies of zooplankton diversity in estuaries (Telesh \& Heerkloss 2002, 2004, Telesh 2004, Telesh et al. 2008a), and revisions of calculations of zooplankton 
species richness in the open Baltic Sea (Telesh et al. 2008b, 2009, Mironova et al. 2009) and the North Sea (Lindley \& Batten 2002). Meta-analysis of data sets was performed using the Microsoft Office Excel program.

All data are taken from published sources (see Table 1). Details of sampling procedures, spatial and temporal distribution of plankton, seasonality, species identification, processing and prime analyses of biological objects are given in the respective sources. The overviews cited in the previous paragraph provide full descriptions of the taxonomic concepts, sampling protocols, and preservation and analysis of the data used for the present study. Standardisation of these research approaches, methodologies and concepts has been achieved in the framework of the activities of the nongovernmental association of the Baltic Marine Biologists (e.g. Rieling et al. 2003, Telesh et al. 2009, and references therein) and incorporated in international governmental conventions and research/monitoring guidelines (e.g. HELCOM 1988, 2001, Harris et al. 2000). The use of long-term data sets meant that the effects of weather conditions, seasonality and climate on overall plankton species diversity and distribution data were reduced.

Number of species observed in (or rather pooled for) the conventional regions of the Baltic Sea (Fig. 1) with certain salinity ranges was selected as a suitable integrative diversity metric for our analysis because (1) species number is the most commonly considered facet and the simplest measure of biodiversity (Purvis \& Hector 2000), and (2) this choice of unit provides the best comparability of our results with the reference data published by Remane (1934).

In the present study, in addition to the routine grouping of planktonic organisms, we step aside from the traditional discrimination of small flagellated algae and heterotrophic nanoflagellates, and dismiss the conventional ascribing of these groups to different ecological categories: phytoplankton and zooplankton. Thus, we take a protistological approach, which combines practically all eukaryotic unicellular organisms (and several small multicellular organisms), regardless of whether they are heterotrophs (protozoa), phototrophs (protophytes) or saprophytes (lower fungi, not studied here), into the kingdom Protista (Corliss 2002).

We considered the classic Remane curve for macrofauna as the reference case, modified it to get a cumulative species-minimum curve (Fig. 2A), and confronted the latter with results of our analyses of plankton diversity in the Baltic Sea.

\section{RESULTS}

The results of our analysis illustrate that overall plankton diversity in the Baltic Sea is very high: 4056
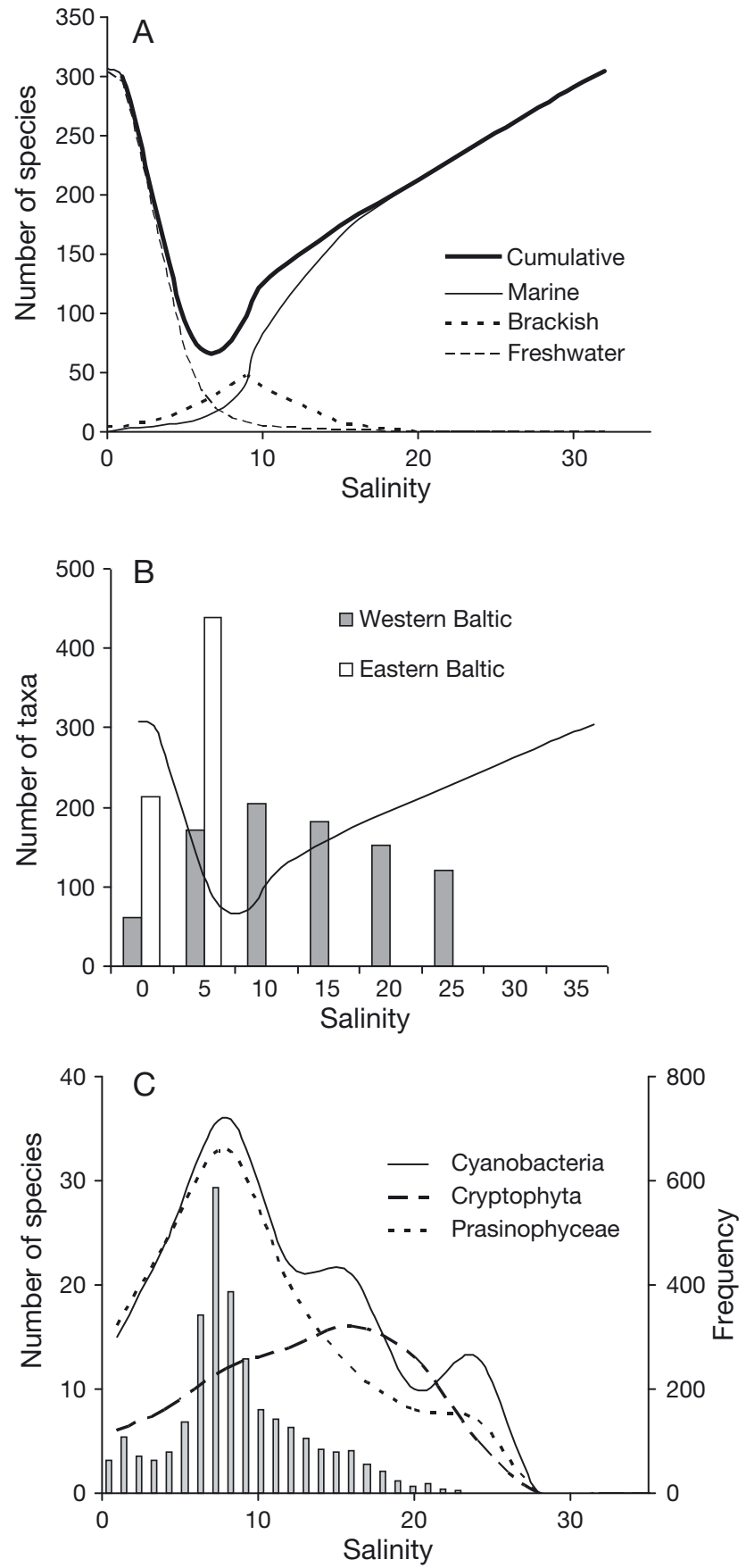

Fig. 2. Diversity of phytoplankton in the salinity gradient versus Remane's curve. (A) Number of marine, brackish and freshwater species and the cumulative species-minimum curve for macrozoobenthos of the Baltic Sea (data from Remane 1934). (B) Total number of phytoplankton taxa (species, genera or families) in the eastern (data for salinity 0 from Telesh et al. 2008a and for salinity 5 from Olenina \& Olenin 2002) and western Baltic Sea (data from Sagert et al. 2008) versus the reconstructed cumulative Remane's curve (solid line). (C) Species number in several phytoplankton taxonomic groups recorded in samples from sites with different salinities along the German Baltic coast (data from Sagert et al. 2008); bars (right $y$-axis) indicate the frequency of occurrence of sites with the respective salinity 
species (Table 1). Phytoplankton as a traditional ecological category demonstrates very high diversity (2666 species) and the most surprising distribution mode, with the highest species richness in the horohalinicum (Fig. 2B). Prokaryotic cyanobacteria (190 species), along with eukaryotic euglenophytes and prasinophytes, show the most clear peaks within the horohalinicum (Fig. 2C), while species numbers of several other taxa (small phototrophic flagellates, cryptophytes) peak at salinity 10 to 15 . Total phytoplankton diversity (including cyanobacteria) in the Baltic Sea counts 2856 species, of which one-third are diatoms. The vertical bars in Fig. $2 \mathrm{C}$ indicate that areas with salinity 5 to 8 prevailed in the sampling sites along the German Baltic coast, which reflects the general frequency of occurrence of the horohalinicum sites and their dominance in the total area of the Baltic Sea (Fig. 1).

Recently revised calculations for zooplankton provide data on 1200 valid species of unicellular (protozooplankton) and multicellular organisms (metazooplankton) and likewise question the assumption of low species diversity in the Baltic Sea (Table 1). The distribution of zooplankton is similar to that of phytoplankton but with higher diversity in freshwater areas (Fig. 3).

Among planktonic metazoans, rotifers and crustaceans are especially species-rich (Table 1). Copepods and cladocerans are most diverse at salinity ca. 3,

Table 1. Phytoplankton and zooplankton species number in the Baltic Sea

\begin{tabular}{|lrl|}
\hline Group of organisms & $\begin{array}{r}\text { No. of } \\
\text { species }\end{array}$ & Data source \\
\hline Cyanobacteria & $\mathbf{1 9 0}$ & Hällfors (2004) \\
Phytoplankton & $\mathbf{2 6 6 6}$ & Hällfors (2004) \\
Heterokontophyta & 1904 & Hällfors (2004) \\
Chlorophyta & 383 & Hällfors (2004) \\
Dinophyta & 232 & Hällfors (2004) \\
Haptophyta & 72 & Hällfors (2004) \\
Euglenophyta & 46 & Hällfors (2004) \\
Cryptophyta & 29 & Hällfors (2004) \\
Zooplankton & $\mathbf{1 2 0 0}$ & Present study \\
Ciliophora & 814 & Telesh et al. (2009) \\
Rotifera & 178 & Telesh \& Heerkloss (2002), \\
& & Telesh et al. (2009) \\
Cladocera & 108 & Telesh \& Heerkloss (2004), \\
Copepoda & & Telesh et al. (2009) \\
& 65 & Telesh \& Heerkloss (2004), \\
Other groups: & $\mathbf{3 5}$ & Telesh et al. (2009) \\
Cnidaria, Ctenophora, & & \\
$\quad$ Chaetognatha, & & \\
Copelata, Turbellaria & & \\
Plankton sum total & $\mathbf{4 0 5 6}$ & Present study \\
\hline
\end{tabular}

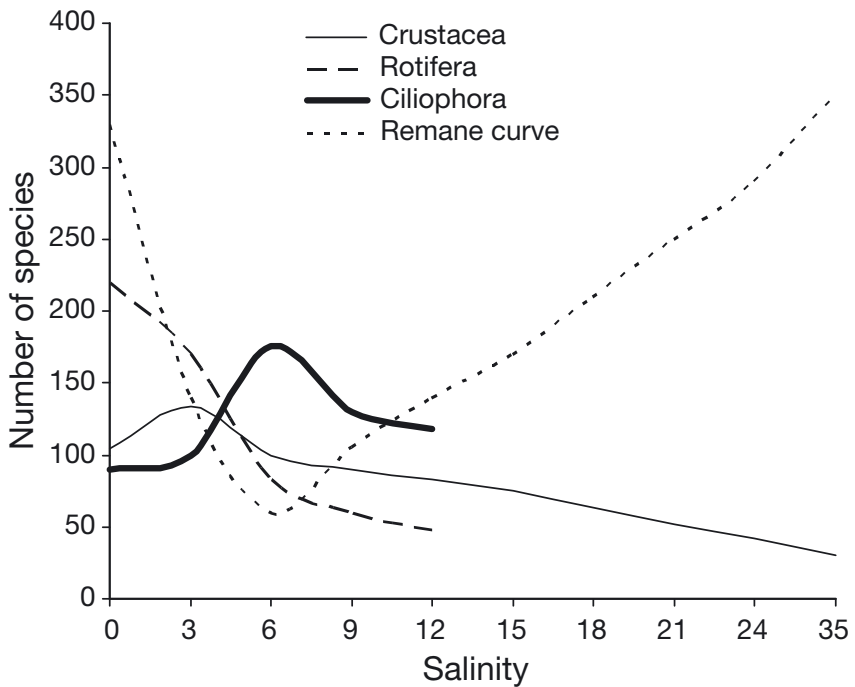

Fig. 3. Zooplankton species diversity in the salinity gradient of the Baltic and North seas: Crustacea (Copepoda and Cladocera), Rotifera, and holoplanktonic Ciliophora (benthopelagic ciliates excluded) versus the reconstructed cumulative Remane's curve. Data for the Baltic Sea from Telesh \& Heerkloss $(2002,2004)$, Telesh et al. (2009); data for the North Sea from Lindley \& Batten (2002)

while species diversity in rotifers diminishes with increasing salinity (Fig. 3). However, none of these metazoan groups follow the species-minimum curve of Remane (Fig. 3).

The greatest zooplankton species diversity is found in ciliates: 814, of which 164 species are holoplanktonic, while the others inhabit presumably near-bottom layers and shallow coastal waters. The species-richness curve for planktonic ciliates shows a maximum at salinity 4 to 8 (Fig. 3).

Thus, data on planktonic organisms with maximum species diversity, i.e. phytoplankton and ciliates, clearly conflict with Remane's species-minimum concept (Figs. 2B \& 3). The protistological approach demonstrates that species numbers of all planktonic Protista in the salinity gradient of the brackish-water Baltic Sea follow a binomial distribution mode, with maximum diversity in the horohalinicum (Fig. 4A), which is at variance with Remane's model. Interestingly, metazooplankton diversity decreases exponentially with salinity; however, it also peaks in the horohalinicum (Fig. 4B). Overall protistan diversity contributes up to $85 \%$ to total planktonic species diversity in the Baltic Sea (Fig. 4C).

\section{DISCUSSION}

Species richness in a water body is closely related to environmental conditions that are largely defined by the degree of variability in the physical and chemical 

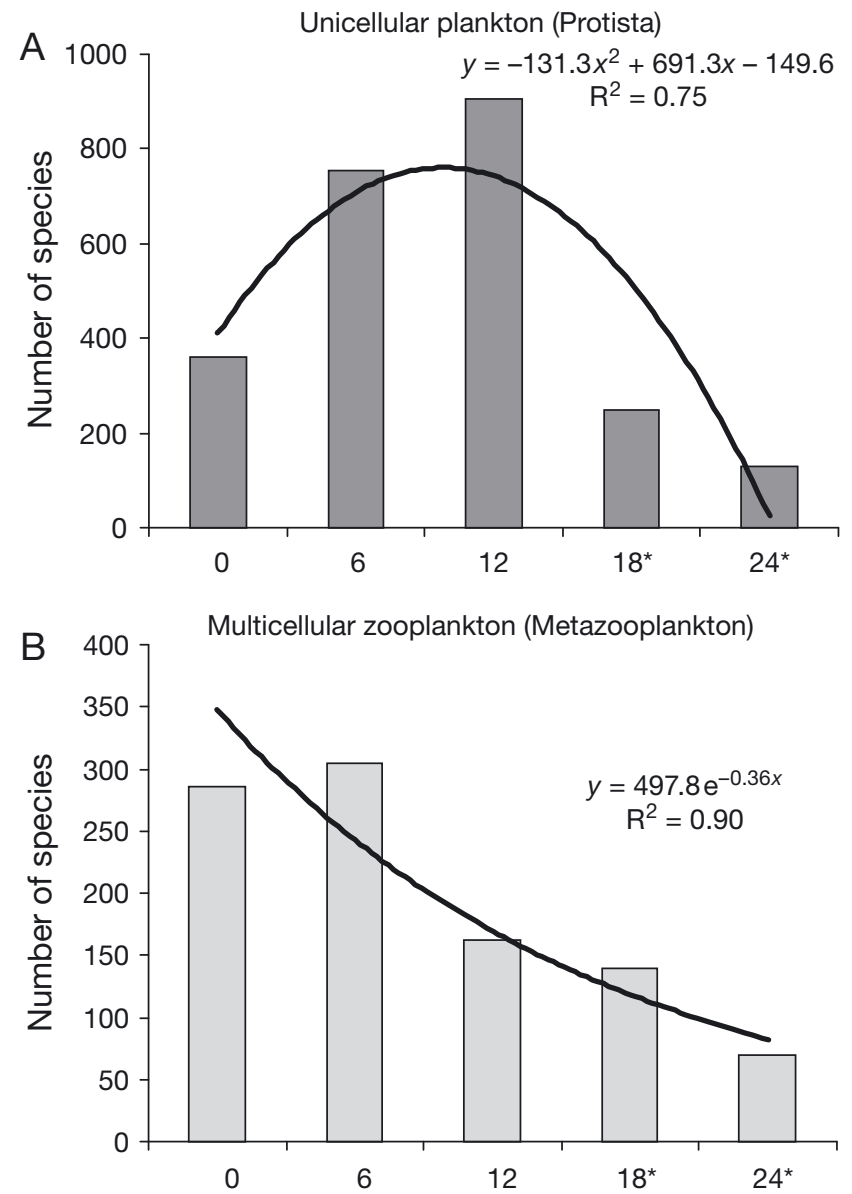

C

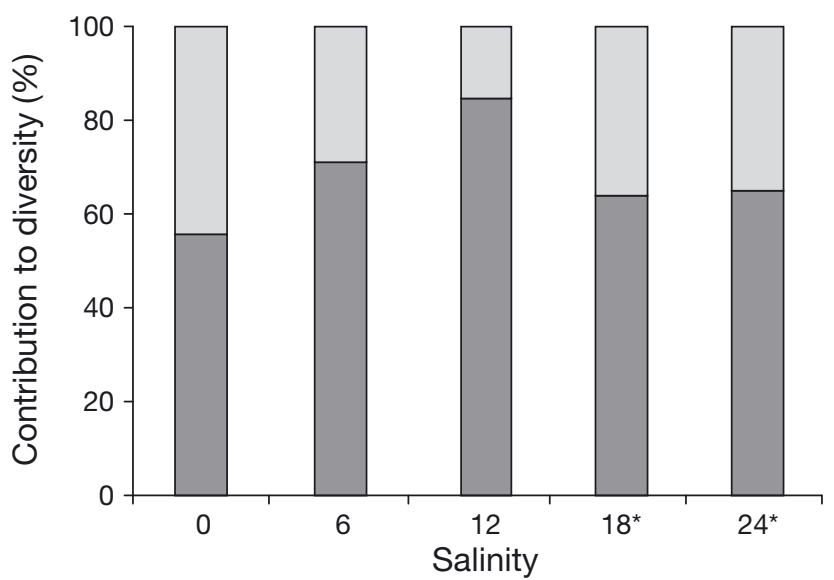

Fig. 4. Diversity of proto- and metazooplankton and their relative contribution to overall pelagic diversity in the salinity gradient of the Baltic Sea. Species number of (A) unicellular planktonic Protista (phytoplankton, heterotrophic flagellates, planktonic and bentho-pelagic Ciliophora) and (B) multicellular zooplankton (metazooplankton), and (C) their contribution to sum total plankton diversity. Trend line curves: binomial distribution of species number of protists (A) and exponential decrease of metazooplankton species number (B) with increasing salinity. ${ }^{*}$ Salinities at which species numbers of ciliates were not available characteristics of the environment (de Jonge 1974, Michaelis et al. 1992, Attrill 2002, Dethier et al. 2010). For example, de Jonge (1974) clearly showed that the diversity of benthic organisms in the small, isolated brackish coastal water bodies of the Netherlands was largely explained by the extreme (maximum and minimum) values and long-term variation in salinity: diversity was high in the water basins with a low coefficient of variation of salinity fluctuations. For estuaries, Attrill (2002) showed that the major environmental factor influencing the distribution of organisms is salinity variation, rather than the organisms' salinity tolerance. Another example demonstrated that the species richness of zoobenthos in small estuaries in the German Bight (North Sea) depended predominantly on habitat diversity in the mesoand oligohaline reaches in relation to the size of the estuary (Michaelis et al. 1992). Those authors found that species richness was relatively high in the estuaries of the larger rivers with greater habitat variety, despite pollution, engineering, shipping and dredging effects. The latest zooplankton results suggest that temporal fluctuations in the physico-chemical environment tend to exclude species from communities while e.g. temperature variability promotes greater species richness (Shurin et al. 2010). However, the net effect of environmental variation on biological diversity is still largely unknown (Huisman \& Weissing 1999, Roelke et al. 2003, de Jonge 2007, Benincá et al. 2008).

In estuaries and brackish-water seas, salinity gradient is the main environmental factor that plays a decisive role and defines structural and functional characteristics of aquatic biota (Telesh \& Khlebovich 2010). Species composition and richness of fauna were among the first biological characteristics investigated in relation to the gradual change in salinity. In the generally tideless Baltic Sea (with only weak tides in the outer fjords; Lass \& Matthäus 2008), which has relatively stable isohalines and smooth salinity gradients in the bays and estuaries, Remane (1934) found an Artenminimum zone (area with minimum number of taxa) within the narrow salinity range of 5 to 8 . Within this salinity range, the relative number of true brackish-water macrozoobenthic species reached a maximum, while species richness of organisms of freshwater or marine origin was sloping towards a minimum (Remane 1934). Zenkewitch (1959) revealed similar Artenminimum zones in the Azov and Caspian seas. Those findings provided arguments for considering the 5 to 8 salinity zone to be a barrier area of 'critical salinity' (Khlebovich 1969), or 'the horohalinicum' (Kinne 1971), where the 2 major types of fauna (marine and freshwater) meet and co-exist wherever a smooth water salinity gradient is present.

However, although accepted as a textbook model for diversity patterns in estuaries and brackish waters, the Artenminimum concept of Remane (1934) has been 
broadly debated for 2 major reasons. First, the Remane diagram has a number of inconsistent features (e.g. poor definitions of both axes and variations in sample location) that make it unsuitable as a quantitative tool for comparing diversity trends between estuaries (Attrill 2002). Second, the Remane model was shown to be inappropriate for some estuarine macrozoobenthos communities (Boesch et al. 1976), meiobenthos (Attrill 2002), phytoplankton (Muylaert et al. 2009), and bacteria and zooplankton of estuarine and brackish waters (Laprise \& Dodson 1994, Crump et al. 1999, Dolan \& Gallegos 2001, Hewson \& Fuhrman 2004, Telesh 2004).

Additionally, different opinions on the existence of genuine brackish-water species (e.g. Barnes 1989, Cognetti \& Maltagliati 2000, Attrill 2002) challenge Remane's curve. Moreover, Remane (1969), while reviewing his earlier considerations of genuine brackishwater species (e.g. Remane 1958), concluded that only a small number of species are really 'genuine' to brackish water in the strict sense of the definition, i.e. show a distribution strictly limited to the mixohaline zones without expansion into the marine or freshwater regions. Wolff (1973) reached the same conclusion in his study of the Rhine-Scheldt delta, which included an extensive review of other estuarine faunas. In many cases, animals classified as 'brackish-water' were confined only regionally to brackish waters due to factors other than salinity (Wolff 1973).

Plankton diversity distribution within the salinity gradient in the Baltic Sea is also inconsistent with the Remane model, as shown by our meta-analysis of large phytoplankton data sets (Sagert et al. 2008), comprehensive phytoplankton species lists (Hällfors 2004), long-term studies of zooplankton diversity in estuaries (Telesh \& Heerkloss 2002, 2004, Telesh 2004, Telesh et al. 2008a), and reanalysis of zooplankton species richness in the open Baltic Sea (Telesh et al. 2008b, 2009, Mironova et al. 2009). Results of our analysis demonstrate high phyto- and zooplankton diversity in the brackish-water Baltic Sea; moreover, for metazooplankton, diversity decreases with increasing salinity, which is largely consistent with the model of Attrill (2002) developed for meiobenthos of the Thames Estuary, UK.

Unicellular planktonic organisms demonstrate a very specific distribution mode, with a peak in diversity in the horohalinicum and high overall species richness in the Baltic Sea. Phytoplankton is especially diverse, at nearly twice the number of algal species in the adjacent, fully saline North Sea, which hosts 1500 phytoplankton species (Hoppenrath 2004). Maximum local phytoplankton diversity in the Baltic Sea occurs in the Curonian Lagoon at salinity 6 (Olenina \& Olenin 2002).

Ciliate diversity in the Baltic Sea (814 species) is higher than in the Black Sea (500 species) and the
Caspian Sea (620 species), mainly because there is better knowledge on bentho-pelagic ciliates in the western Baltic (Telesh et al. 2008b, 2009, Mironova et al. 2009). These bentho-pelagic ciliates contribute significantly to overall plankton diversity in the Baltic Sea due to the large total area of coastal zones (Schiewer 2008), wind-induced water mixing, and upwelling events (Lehman \& Myberg 2008). Such a large taxonomic diversity in ciliates may be attributed to the ubiquity of free-living protists in the temperate climatic zone in general (Fenchel \& Finlay 2004), although this 'everything is everywhere' concept has been debated in recent years (Fuhrman 2009). However, the horohalinicum zone in the Baltic Sea presumably supports protistan species with a broad range of environmental tolerance (Telesh \& Khlebovich 2010).

Meanwhile rotifers, the smallest planktonic metazoans and the zooplankton group with the secondhighest diversity in the Baltic Sea, find room on the freshwater 'wing' of Remane's curve, which is of little surprise, as the majority of known rotifer species generally inhabit freshwater environments (Nogrady et al. 1993). Rotifer diversity and the overall Baltic metazooplankton diversity trends (Figs. 3 \& 4B) are likewise inconsistent with the Remane diagram and fit instead to Attrill's model (compare with Fig. 5 in Attrill 2002).

The results suggest that, in contrast to Remane's Artenminimum curve for bottom-dwelling animals (Remane 1934) and unlike macroalgae (Schubert \& Schories 2008), pelagic diversity dominated by protists in the Baltic Sea peaks in the horohalinicum, giving grounds to the protistan species-maximum concept. The protistological approach (Corliss 2002) facilitated the search for possible explanations of the proposed concept: the ecological, evolutionary, molecular-genetic and physiological aspects of protistan biology. Indeed, some marine and freshwater species have evolved a tolerance to intermediate salinities or to salinity fluctuations and can therefore live in brackish waters. Salinities of 5 to 8 and a change in the ionic composition of seawater at these or even lower salinities are known to form an eco-physiological barrier zone for aquatic animals and plants, impeding high biodiversity in or below the horohalinicum (Khlebovich 1969, Kinne 1971). Some studies suggest, however, that aquatic organisms are more sensitive to changes in total osmotic pressure, which is especially stressing at salinity 0.5 to 1.0 , than to ion content in water and salinity gradient at 5 to 8 (Deaton \& Greenberg 1986). These findings are supported by the concept of the plurality of barrier salinity zones developed by Aladin (1988), who distinguished multiple horohalinicum areas in the Baltic Sea, including a specific $\delta$-horohalinicum zone at salinities $<2$.

Meanwhile, field and experimental evidence exists for a wide salinity tolerance in many common ciliated 
species capable of fast broad-range salinity adaptations that let them prosper even in an osmotically adverse environment (Stock et al. 2002). Ciliates have developed powerful strategies for responding to salinity stress and display unique ionic activities of contractile vacuoles (where present) and very peculiar cellular osmoregulation. Recent findings have made a major breakthrough in understanding the fine organisation and functioning of contractile vacuoles during and after stress, their fast recovery and functional resumption (Stock et al. 2002). Besides, ciliates and many other protists are capable of cyst formation in stressful conditions (Corliss 2002) as well as fast reproduction and significant genetic variability (Fuhrman 2009) that provide these unicellular organisms with powerful eco-physiological and molecular means for successful adaptation to life within the permanent salinity gradient in the horohalinicum of the Baltic Sea.

The high speciation rate of small planktonic organisms can be considered as a prerequisite that increases the probability of achieving osmoregulation capabilities, allowing the microscopic organisms to survive in brackish environments, irrespective of their origin, i.e. whether they came to these habitats from freshwater or marine habitats. In general, organisms in brackish waters have to be (and many of them are) cosmopolitan, because brackish systems (e.g. horohalinicum zones in estuaries) are usually of short duration and not directly interconnected with each other. Even the Baltic Sea - the largest brackish-water sea in the world, which has a water-residence time of 25 to $35 \mathrm{yr}$ and has been in a 'Mya period' for the last $2000 \mathrm{yr}$ (Lass \& Matthäus 2008) -is still too young to evolve larger brackish-water organisms. Consequently, the number of endemic species in the Baltic is very low, and there are almost no 'pure brackish-water' species, as shown earlier (Remane 1969, Wolff 1973).

The small planktonic protists that are able to tolerate brackish conditions and maintain high species diversity have, most probably, evolved successively in a series of transient brackish habitats. Arriving in the relatively stable Baltic horohalinicum from both sides, marine as well as freshwater, but still not being brackish-water specialists, many of the planktonic protists in this sea have a broad salinity-tolerance range, with the optimum salinity close to horohalinicum values (Stock et al. 2002, Mironova et al. 2009, and references therein). Their high species richness in the horohalinicum may be also explained by the fact that plankton in general drift within large water masses and thus live in a more stable environment and experience less stress from moderate salinity fluctuations, compared with benthic animals and macrophytes. This phenomenon is best illustrated by the structure of the Baltic pelagic communities formed in the conditions of an exceptionally stable salinity gradient exposed within a large, sea-scale area (Fig. 1).

The brackish-water Baltic Sea thus represents a clear example of how pelagic biodiversity in a large osmotically stressed though relatively stable ecosystem is promoted when fast-growing evolutionarily advanced small-sized protists are abundant, constituting up to $85 \%$ of total plankton diversity (Fig. 4C). This viewpoint is supported by the intermediate disturbance hypothesis (Connell 1978, Reinolds et al. 1993) as well as by the body-size dependency of the evolutionary rate (Fenchel \& Finlay 2004). We can also speculate that the reduced competitiveness within the Baltic horohalinicum allows the coexistence of a large variety of microplanktonic protistan species, especially the bentho-pelagic ones, due to lower species diversity in benthic invertebrates, which are more susceptible to salinity fluctuations. Among these protists, ciliates are the most efficient consumers of total primary and bacterial production (Telesh et al. 2009 and references therein); however, none of them is capable of consuming the excessive resources completely and hence outcompeting the others. These assumptions are well supported by resource competition theory (Tilman 1982, Grover 1997, Huisman \& Weissing 1999, 2001). Moreover, as the horohalinicum occupies the major area of the Baltic Sea, such high protistan diversity is fairly concordant with the species-area relationship established for protists (Gaston 2000, Fenchel \& Finlay 2004, Fuhrman 2009), which play a key role in maintaining sustainable ecosystem functions (Hector \& Bagchi 2007). Our new findings thus contribute to the debate on ecosystem stability and the insurance hypothesis (McCann 2000).

On the temporal macro-scale, evolutionary processes are usually thought to be the ultimate cause of low biological diversity in brackish waters. This suggests a dependence of biodiversity on a delicate balance between the supply of seawater and freshwater, which is unlikely to remain relatively constant long enough to allow a distinct, species-rich flora and fauna to evolve; consequently, the key stressor may not be the absolute range of critical salinity but, rather, the scale of its temporal variation (Dethier et al. 2010). The Baltic Sea, however, represents a unique case of a permanent salinity gradient that provides its pelagic inhabitants with long-lasting conditions of relatively stable low-level salinities in a large area of water. Thus, the Baltic protists have received an enduring chance for physiological adaptation and evolution towards euryhalinity. Resolving principal processes underlying this remarkable phenomenon may provide a key to understanding global patterns in brackishwater biodiversity (Telesh \& Khlebovich 2010). Against this macro-ecological background, small body sizes, 
rapid growth, huge populations, and advanced adaptability to environmental stresses define the cosmopolitanism and high species richness of protists in various environments (Corliss 2002, Fenchel \& Finlay 2004). Results of these findings can be used to address several timely issues, e.g. reducing the uncertainty of ecosystem energy balance and climate models (Edwards \& Richardson 2004), or searching for general biodiversity patterns that might apply to all domains of life, thereby improving our theories and their predictive power.

\section{CONCLUSIONS}

The present study shows that the earlier conception of low species diversity in the brackish-water Baltic Sea had resulted from insufficient knowledge on the taxonomic composition of the sea's zooplankton and phytoplankton. Plankton communities in the Baltic Sea are extremely diverse, totaling at least 4056 species, and this fact is critical to be able to shake loose from the outdated 'the Baltic Sea is species-poor' viewpoint. Unlike the low species diversity among bottomdwelling animals and macroalgae, the pelagic species diversity in the Baltic Sea is strikingly high; it is defined mainly by protists whose species richness peaks in the horohalinicum, giving a basis for the protistan species-maximum concept. The horohalinicum, thus, sets an upper limit on species richness for larger, sedentary or rooted forms of life, but other factors can increase this limit for small protists drifting within large water masses. We assume that principally ecological, eco-physiological and evolutionary reasons have allowed the small-sized fast evolvers, the protists, to develop considerable species richness and fill in the biodiversity gap in the brackish-water Baltic Sea. This new knowledge is transforming our view of biodiversity in transition areas by refining the Remane model, and discriminating between salinity effects on species diversity in large sessile versus small motile aquatic organisms in a fluctuating environment.

Acknowledgements. We thank H. MacIsaac for critical comments on the manuscript at the initial stage of its preparation. V. N. de Jonge and 2 anonymous reviewers are gratefully acknowledged for their valuable comments and suggestions that significantly improved the manuscript. We acknowledge the facilities of the Zoological Institute and the Institute of Cytology at the Russian Academy of Sciences, St. Petersburg, Russia, and the University of Rostock, Germany. The work was supported by the Russian Foundation for Basic Research (projects 10-04-00943 and 10-04-90420), grant \#3276.2010.4 for the Leading Scientific School from the Russian Ministry of Education and Science, the Program of the Presidium of the Russian Academy of Sciences 'Scientific basics for biodiversity conservation in Russia', the German Federal Ministry of
Education and Research (IB/BMBF projects RUS 07/001 and RUS 09/038), and the German Research Council (DFG project Schu 983/5-1).

\section{LITERATURE CITED}

Aladin NV (1988) The concept of relativity and plurality of barrier salinity zones. Zh Obshch Biol 49:825-833 (in Russian)

Attrill MJ (2002) A testable linear model for diversity trends in estuaries. J Anim Ecol 71:262-269

Barnes RSK (1989) What, if anything, is a brackish water fauna? Trans R Soc Edinb Earth Sci 80:235-240

> Benincá E, Huisman J, Heerkloss R, Johnk KD and others (2008) Chaos in a long-term experiment with a plankton community. Nature 451:822-827

> Boesch DF, Diaz RJ, Virnstein RW (1976) Effects of Tropical Storm Agnes on soft-bottom macrobenthic communities of the James and York estuaries and the lower Chesapeake Bay. Chesapeake Sci 17:246-259

> Cognetti G, Maltagliati F (2000) Biodiversity and adaptive mechanisms in brackish water fauna. Mar Pollut Bull 40: $7-14$

> Connell JH (1978) Diversity in tropical rain forests and coral reefs. Science 199:1302-1303

Corliss JO (2002) Biodiversity and biocomplexity of the protists and an overview of their significant roles in maintenance of our biosphere. Acta Protozool 41:199-219

Crump BC, Armbrust EV, Baross JA (1999) Phylogenetic analysis of particle-attached and free-living bacterial communities in the Columbia River, its estuary, and the adjacent coastal ocean. Appl Environ Microbiol 65:3192-3204

de Jonge VN (1974) Classification of brackish coastal inland waters. Hydrobiol Bull 8:29-39

de Jonge VN (2007) Toward the application of ecological concepts in EU coastal water management. Mar Pollut Bull 55:407-414

> de Jonge VN, de Jong DJ (2002) Ecological restoration in coastal areas in the Netherlands: concepts, dilemmas and some examples. Hydrobiologia 478:7-28

Deaton LE, Greenberg MJ (1986) There is no horohalinicum. Estuaries 9:20-30

Dethier MN, Ruesink J, Berry H, Sprenger AG, Reeves B (2010) Restricted ranges in physical factors may constitute subtle stressors for estuarine biota. Mar Environ Res 69: $240-247$

> Dolan JR, Gallegos CL (2001) Estuarine diversity of tintinnids (planktonic ciliates). J Plankton Res 23:1009-1027

> Edwards M, Richardson AJ (2004) Impact of climate change on marine pelagic phenology and trophic mismatch. Nature 430:881-884

Feistel R, Weinreben S, Wolf H, Seitz S and others (2010) Density and absolute salinity of the Baltic Sea 2006-2009. Ocean Sci 6:3-24

Fenchel T, Finlay BJ (2004) The ubiquity of small species: patterns of local and global diversity. Bioscience 54:777-784

Fuhrman JA (2009) Microbial community structure and its functional implications. Nature 459:193-199

Gaston KJ (2000) Global patterns in biodiversity. Nature 405:220-227

Grover JP (1997) Resource competition. Chapman \& Hall, London

Hällfors G (2004) Checklist of Baltic Sea phytoplankton species (including some heterotrophic protistan groups). Baltic Sea Environ Proc 95:1-208

Harris RP, Wiebe PH, Lenz J, Skjoldal HR, Huntley M (eds) 
(2000) ICES zooplankton methodology manual. Academic Press, San Diego, CA

Hector A, Bagchi R (2007) Biodiversity and ecosystem multifunctionality. Nature 448:188-190

HELCOM (1988) Guidelines for the Baltic Monitoring Programme for the Third Stage. Part D. Biological determinants. Baltic Sea Environ Proc 27D

HELCOM (2001) Environment of the Baltic Sea area 19941998. Baltic Sea Environ Proc 82A:1-24

Hernroth L, Ackefors H (1979) The zooplankton of the Baltic proper. A long-term investigation of the fauna, its biology and ecology. Rep Fish Bd Sweden, Inst Mar Res 2:1-60

Hewson I, Fuhrman JA (2004) Richness and diversity of bacterioplankton species along an estuarine gradient in Moreton Bay, Australia. Appl Environ Microbiol 70:3425-3433

> Hoppenrath M (2004) A revised check-list of planktonic diatoms and dinoflagellates from Helgoland (North Sea, German Bight). Helgol Mar Res 58:243-251

Huisman J, Weissing FJ (1999) Biodiversity of plankton by species oscillations and chaos. Nature 402:407-410

Huisman J, Weissing FJ (2001) Fundamental unpredictability of multispecies competition. Am Nat 157:488-494

Khlebovich VV (1968) Some peculiar features of the hydrochemical regime and the fauna of mesohaline waters. Mar Biol 2:47-49

Khlebovich VV (1969) Aspects of animal evolution related to critical salinity and internal state. Mar Biol 2:338-345

Khlebovich VV, Abramova EN (2000) Some problems of crustacean taxonomy related to the phenomenon of horohalinicum. Hydrobiologia 417:109-113

Kinne O (1971) Marine ecology. A comprehensive, integrated treatise on life in oceans and coastal waters, Vol 1: Environmental factors, Part 2. Wiley Interscience, London

Laprise R, Dodson JJ (1994) Environmental variability as a factor controlling spatial patterns in distribution and species diversity of zooplankton in the St. Lawrence Estuary. Mar Ecol Prog Ser 107:67-81

Lass HU, Matthäus W (2008) General oceanography of the Baltic Sea. In: Feistel R, Nausch G, Wasmund N (eds) State and evolution of the Baltic Sea 1952-2005. John Wiley \& Sons, Hoboken, NJ, p 5-44

Lehman A, Myberg K (2008) Upwelling in the Baltic Sea: a review. J Mar Syst 74:4-12

Lindley JA, Batten SD (2002) Long-term variability in the diversity of North Sea zooplankton. J Mar Biol Assoc UK 82:31-40

McCann KS (2000) The diversity-stability debate. Nature 405: 228-233

McLusky DS, Elliott M (2004) The estuarine ecosystem: ecology, threats and management, 3rd edn. Oxford University Press, Oxford

Michaelis H, Fock H, Grotjahn M, Post D (1992) The status of the intertidal zoobenthic brackish-water species in estuaries of the German Bight. Neth J Sea Res 30:201-207

Mironova EI, Telesh IV, Skarlato SO (2009) Planktonic ciliates of the Baltic Sea. Inland Water Biol 2:13-24

Muylaert K, Sabbe K, Vyverman W (2009) Changes in phytoplankton diversity and community composition along the salinity gradient of the Schelde estuary (Belgium/The Netherlands). Estuar Coast Shelf Sci 82:335-340

Nogrady T, Wallace RL, Snell TW (1993) Rotifera. 1. Biology, ecology and systematics. SPB Academic Publishing, The Hague

- Ojaveer H, Jaanus A, MacKenzie BR, Martin G and others (2010) Status of biodiversity in the Baltic Sea. PLoS ONE 5:e12467

Olenina I, Olenin S (2002) Environmental problems of the south-eastern Baltic coast and the Curonian Lagoon. In: Schernewski G, Schiewer U (eds) Baltic coastal ecosystems: structure, function and coastal zone management. Springer-Verlag, Berlin, p 149-156

Paavola M, Olenin S, Leppäkoski E (2005) Are invasive species most successful in habitats of low native species richness across European brackish water seas? Estuar Coast Shelf Sci 64:738-750

Purvis A, Hector A (2000) Getting the measure of biodiversity. Nature 405:212-219

Redeke HC (1933) Über den jetzigen Stand unserer Kenntnisse der Flora und Fauna der Brackwassers. Verh Int Verein Limnol 6:46-61

Reinolds CS, Padisák J, Sommer U (1993) Intermediate disturbance in the ecology of phytoplankton and maintenance of species diversity: a synthesis. Hydrobiologia 249:183-188

Remane A (1934) Die Brackwasserfauna. Zool Anz 7 (Suppl): $34-74$

Remane A (1958) Ökologie des Brackwassers. In: Remane A, Schlieper C (eds) Die Biologie des Brackwassers. Binnengewässer 22:1-216

Remane A (1969) Wie erkennt man eine genuine Brackwasserart? Limnologica 7:9-21

Remane A, Schlieper C (1971) Biology of brackish water, 2nd revised edn. John Wiley \& Sons, New York, NY

Rieling T, Sagert S, Bahnwart M, Selig U, Schubert H (2003) Definition of seasonal phytoplankton events for analysis of long-term data from coastal waters of the southern Baltic Sea with respect to the requirements of the European Water Framework Directive. In: Brebbia CA, Almorza D, Sales D (eds) Proc 7th Int Conf Water Pollut, Cadiz. WIT Press, Southampton, p 103-113

Roelke D, Augustine S, Buyukates Y (2003) Fundamental predictability of multispecies competition: the influence of large disturbance. Am Nat 162:615-623

Sagert S, Rieling T, Eggert A, Schubert H (2008) Development of a phytoplankton indicator system for the ecological assessment of brackish coastal waters (German Baltic Sea coast). Hydrobiologia 611:91-103

Schiewer U (2008) Ecology of Baltic coastal waters. SpringerVerlag, Berlin

Schubert H, Schories D (2008) Macrophytobenthos. In: Feistel R, Nausch G, Wasmund N (eds) State and evolution of the Baltic Sea 1952-2005. John Wiley \& Sons, Hoboken, NJ, p 483-542

Shurin JB, Winder M, Adrian R, Keller WB and others (2010) Environmental stability and lake zooplankton diversitycontrasting effects of chemical and thermal variability. Ecol Lett 13:453-463

Stock C, Grønlien HK, Allen RD, Naitoh Y (2002) Osmoregulation in Paramecium: in situ ion gradients permit water to cascade through the cytosol to the contractile vacuole. J Cell Sci 115:2339-2348

- Telesh IV (2004) Plankton of the Baltic estuarine ecosystems with emphasis on Neva Estuary: a review of present knowledge and research perspectives. Mar Pollut Bull 49:206-219

Telesh IV, Heerkloss R (2002) Atlas of estuarine zooplankton of the southern and eastern Baltic Sea. Part I: Rotifera. Verlag Dr. Kovač, Hamburg

Telesh IV, Heerkloss R (2004) Atlas of estuarine zooplankton of the southern and eastern Baltic Sea. Part II: Crustacea. Verlag Dr. Kovač, Hamburg

> Telesh IV, Khlebovich VV (2010) Principal processes within the estuarine salinity gradient: a review. Mar Pollut Bull 61:149-155

Telesh IV, Golubkov SM, Alimov AF (2008a) The Neva Estuary ecosystem. In: Schiewer U (ed) Ecology of Baltic 
coastal waters. Ecol Stud 197:259-284

Telesh I, Postel L, Heerkloss R, Mironova E, Skarlato S (2008b) Zooplankton of the open Baltic Sea: atlas. BMB Publ 20. Meereswiss Ber Warnemünde 73:1-251

Telesh I, Postel L, Heerkloss R, Mironova E, Skarlato S (2009) Zooplankton of the open Baltic Sea: extended atlas. BMB Publ 21. Meereswiss Ber Warnemünde 76:1-290

Tilman D (1982) Resource competition and community structure. Princeton University Press, Princeton, NJ

Välikangas I (1926) Planktologische Untersuchungen im Hafengebiet von Helsingfors. Acta Zool Fenn 1:1-298

Välikangas I (1933) Über die Biologie der Ostsee als Brackwassergebiet. Verh Int Verein Limnol 6:62-112

Venice System (1959) The final resolution of the symposium

Editorial responsibility: Hans Heinrich Janssen,

Oldendorf/Luhe, Germany on the classification of brackish waters. Arch Oceanogr Limnol 11(Suppl):243-248

Wattenberg H (1949) Entwurf einer natürlichen Einteilung der Ostsee. Kieler Meeresforsch 6:10-15

Wolff WJ (1973) The estuary as a habitat. An analysis of data on the soft-bottom macrofauna of the estuarine area of the rivers Rhine, Meuse and Scheldt. Zool Verh Leiden 126: $1-242$

Wolff WJ (1983) Estuarine benthos. In: Ketchum BH (ed) Ecosystems of the world 26: estuaries and enclosed seas. Elsevier, Amsterdam, p 151-183

Zenkewitch LA (1959) The classification of brackish-water basins as exemplified by the seas of the U.S.S.R. Arch Oceanogr Limnol 11:53-61

Submitted: July 23, 2010; Accepted: November 11, 2010

Proofs received from author(s): January 4, 2011 